\title{
Integrated planning: a sustainable urban mobility concept for the Jiu Valley
}

\author{
Mihai-Ionut Danciu ${ }^{1, *}$, and Sabina Irimie $^{2}$ \\ ${ }^{1}$ Politehnica University, 300223, Traian Lalescu, 2A, Timisoara, Romania \\ 2 Petrosani University, 332006, Universitatii, 20, Petrosani, Romania
}

\begin{abstract}
Former industrial areas are characterized by transport infrastructures that exceed the national average in terms of development, spatial coverage and initial investments. Today, when production is replaced by services, retail and consumption, these networks are seen as amenities that have the ability to address the main local issues: the vulnerable economic flows, the lack of accessibility in poor or remote areas, urban shrinkage and the lack of coordination in spatial planning. This study reviews the current status of sustainable urban mobility plans in each of the six towns that form the Jiu Valley and correlates them with the local development strategies and plans. The main positive and negative aspects are highlighted to create an objective overview regarding the vision for mobility in Jiu Valley, as a whole. In the final part, we propose an integrated planning methodology for the entire urban area, envisioning a sustainable productive urban area, formed by accessible communities with strong identities, expressing a circular economic metabolism integrated in the regional development strategy.
\end{abstract}

\section{Introduction}

According to the latest legislative changes in Romania [1-2], planning is regarded as the main activity that can determine the economic and territorial development in all levels, from the state down to the local government. There are two types of planning documents: strategic plan and spatial development plans. The former are the creation and responsibility of various types of practitioners, from urbanists to economists and local administration experts. The latter is created by urbanists and architects that coordinate a multidisciplinary team of experts. Hierarchically speaking, the most important are the strategic plans, followed by the spatial development strategies. The latter must be drafted according to the former. Also, in order to receive financial European aids, every project must be mentioned in the local development strategic Plan.

In the Jiu Valley, there are six local administrative territorial units (ATU): Petrila, Petrosani, Aninoasa, Vulcan, Lupeni and Uricani. Each of them approved a local development strategy that corresponds to the 2007-2013 European financial exercise, but not all of them established a strategy for the 2014-2020 interval. Also, only some of the six cities are planning to renew their General Urban Plan (GUP), even though some of the current

* Corresponding author: mihaiidanciu@yahoo.com 
GUPs are approved around 2000, when mining was still the main driving force for economic activity in the area. The rules for the application of Law no. 350/2001 on regional planning and development and updating of planning documents [3] state that every new GUP must be based on substantiation studies of several types, including the Sustainable Urban Mobility Plan (SUMP) and the Study regarding the Evolution of Economic Activities (SEEA). In theory, they must be the documents that give the main directions regarding the development of economy and mobility in every ATU. Practically, as we will see in this study, only one town (Petrosani) acknowledges the necessity of these studies and their essential role in their sustainable development. This is also the one municipality that needs to become the centre of the new mobility-oriented paradigm. Drawing a line as a conclusion in the failure of strategic local planning, this study proposes an objective overview concept that engages the most important and feasible assets of the Valley: the transport infrastructure and the concentration of human activities along the main transport network.

\section{Methodology}

The research uses qualitative methods to evaluate the strategic planning of each local administration in the Jiu Valley and finds gaps between planning and the actual needs of the local socio-economic context. Then, it uses the information received after a regular request was placed, in January 2017, at each mayor's office, enquiring for the status of each of the relevant documents in strategic local planning, in order to present their capacity to respond to the current spatial development challenges. Following the guidelines of OECD [4], and the demonstration regarding the sustainability of rail transport in both local and regional contexts, the study comes in the final part and proposes an alternative that checks the main sustainability goals for the Jiu Valley.

\section{Mobility and Urban Development Strategies}

\subsection{Strategic documents}

The $\mathrm{XXI}^{\mathrm{st}}$ century is dominated by mobility [5], a concept involving people, goods, natural elements, ideas and technologies. This is one of the emerging sign of the fourth industrial revolution, one that creates the so-called Industry 4.0, a contemporary trend that brings together automation and data exchange to create new manufacturing technologies. Considering these, urban development becomes a matter of negotiation between citizens, local administration and stakeholders and the regulation of the processes that occur inside the urban area and in relation to the surrounding environment. The city becomes an organism in itself, governed by a metabolism that can either develop its structure (organic development) or let it decrease (smart shrinking or destruction).

The main purpose of strategies in the context of the European Union is sustainability, through the meanings of protection, strengthening and further development of the cities [6]. European cities are acknowledged as possessing unique cultural and architectural qualities, a multiculturality that supports social inclusion of the vulnerable groups and great possibilities for economic development. Cities are the centre of knowledge and the sources for innovation and growth.

In this context, the role of the Sustainable Urban Mobility Plan (SUMP) is to consider each coherent urban core as the centre of a functional urban area and to introduce coherence in cooperation between sectors, policy areas, levels of administration, citizens and other stakeholders. This strategic plan is not just a concept regarding the development of the mobility in the Functional Urban Area, but it is also a section through all the strategic 
documents that have an impact in the urban area, from the national to the local level, from the socio-economic point of view to the territorial (or physical) field. This is the reason why we consider this as being the most important document that sustain the intentions of local authorities. In addition to this, we consider the Study regarding the Evolution of Economic Activities (SEEA), a founding study for the General Urban Plans that have to be revised, by 2018 , in every city. It is the most important economic document that establishes the main drivers for local sustainable economic development, based on the historic background, the current level of development and the economic trends that can impact the local context. Taken together, SUMP and SEEA establish the main directions for urban development and should be the main documents consulted when local authorities decide to renew the urban plans and the local development strategies.

\subsection{Contemporary urban mobility trends}

In the field of mobility, the most efficient transit systems are the light rail for inner city areas and the commuter train in suburbia [4]. These two have to be combined with small scale means, as pedestrian and bicycle corridors, in order to be the most efficient (related to costs, time and impact on the environment) in complex urban systems. Railroad was introduced in central and eastern part of Europe in the second half of the XIX ${ }^{\text {th }}$ century, mainly because of the Austrian politics regarding the extraction and processing of resources from the main dependent areas of the empire. Railroads were built on the perimeter of settlements, where the stations were also located, usually in relation to a main thoroughfare or a street connection to the centre of the settlement. Also, the new industrial developments occurred in this part of the settlements, usually behind the station and in direct relation to the rail lines.

Today, new trends in mobility recognize the situation presented above as being favourable for a new type of development, based on density and mixed use functions. According to the European Commission [6], the future of European mobility resides in high speed lines and new urban cores (NUC) developed around the main passenger stations. The former traditional railway station becomes the new city centre, creating a link between the traditional city centre and the former industrial or backstreet area, now in a complex state of redevelopment. These new areas are a mixture between new buildings (mainly offices and small scale production) and restored historic facilities.

Also, a new concept emerged in Western Europe: the tram-train system (TT). It uses the advantages of both tramway (short distances and high accessibility) and commuter trains (relation between urban settlements and the hinterland and higher speeds) to reconnect functional urban cores to the surrounding territory. By using the same gauge and electricity supply system, the tram-train system starts to be implemented even in the Eastern part of Europe, as we can see in the projects of Timisoara and Szeged [6].

Overlapping the two concepts (tram-train and new urban cores around the main rail stations), we can easily extract the third most important trend influencing our subject: Transit Oriented Development (TOD). As it is named, it is a type of development focused around transit, bringing new residential buildings, business hubs and a valuable public leisure space close to the transit stations. It resides upon the basic characteristic of urban areas: density. The higher the density of urban functions, the more effective is the use of space and public spending, and in the same time developing sustainable in economic and social terms.

In conclusion for this chapter, we can underline that urban development is strongly related to mobility, the former usual railway stations becoming the centre of the urban regeneration, one based on efficiency in the use of public funds. 


\section{Current strategic planning in the Jiu Valley}

In the context of a former mining region, as the Jiu Valley will be after 2018, the most important role in local development resides upon the leadership of local administrations [7]. To test the transparency of local administrations, in January $25^{\text {th }}$ we placed a request at each local administration, asking for the main local development documents. We asked to receive the information via e-mail, or via mail, based on the Law 544/2004 regarding the free access to public information. The results are presented in table 1 , below.

Table 1. Result of the basic request for local development strategy (LDS) 2014-2020, SUMP and SEEA, from each local authority in the Jiu Valley

\begin{tabular}{|c|c|c|c|c|c|c|}
\hline $\begin{array}{l}\text { No. of } \\
\text { request }\end{array}$ & Town & $\begin{array}{l}\text { Answer } \\
\text { medium }\end{array}$ & $\begin{array}{l}\text { Days after } \\
\text { the request } \\
\text { was placed }\end{array}$ & $\begin{array}{l}\text { Answer } \\
\text { for } \\
\text { SUMP }\end{array}$ & $\begin{array}{l}\text { Answer for } \\
\text { SEEA }\end{array}$ & $\begin{array}{l}\text { Answer for } \\
\text { LDS }\end{array}$ \\
\hline $\begin{array}{c}10980 / \\
2017\end{array}$ & Vulcan & e-mail & 27 & \multicolumn{3}{|c|}{$\begin{array}{l}\text { invited to study documents, but not } \\
\text { specified their nature }\end{array}$} \\
\hline $\begin{array}{c}2186 / \\
2017\end{array}$ & Petrila & e-mail & 1 & $\begin{array}{l}\text { There is } \\
\text { no SUMP }\end{array}$ & $\begin{array}{l}\text { There is no } \\
\text { SEEA but } \\
\text { offered some } \\
\text { information }\end{array}$ & $\begin{array}{l}\text { There is an } \\
\text { LDS, } \\
\text { posted on } \\
\text { the website }\end{array}$ \\
\hline $\begin{array}{l}875 / \\
2017\end{array}$ & Petrosani & $\begin{array}{l}\text { conventional } \\
\text { mail }\end{array}$ & ${ }^{2} 26$ & $\begin{array}{l}\text { SUMP in } \\
\text { approval } \\
\text { phase }\end{array}$ & $\begin{array}{l}\text { No answer for } \\
\text { SEEA }\end{array}$ & $\begin{array}{l}\text { (there is an } \\
\text { LDS, } \\
\text { posted on } \\
\text { the website) }\end{array}$ \\
\hline $\begin{array}{l}365 / \\
2017\end{array}$ & Uricani & - & - & - & - & - \\
\hline $\begin{array}{l}870 / \\
2017\end{array}$ & Lupeni & e-mail & 22 & $\begin{array}{l}\text { There is } \\
\text { no SUMP }\end{array}$ & $\begin{array}{l}\text { There is no } \\
\text { SEEA but } \\
\text { offered some } \\
\text { information }\end{array}$ & $\begin{array}{l}\text { Received } \\
\text { LDS via } \\
\text { email }\end{array}$ \\
\hline $\begin{array}{l}264 / \\
2017\end{array}$ & Aninoasa & e-mail & 1 & $\begin{array}{l}\text { There is } \\
\text { no SUMP }\end{array}$ & $\begin{array}{l}\text { There is no } \\
\text { SEEA but } \\
\text { offered some } \\
\text { information }\end{array}$ & $\begin{array}{c}\text { There is no } \\
\text { LDS yet }\end{array}$ \\
\hline
\end{tabular}

There are two local administrations that proved to be very responsive, Petrila and Aninoasa. Uricani City Hall did not respond to our request. As we expected, even if the legal term to renew the General Urban Plans in Romania is January 1st, 2018, three out of the six local administrations did not even begin the process. Vulcan did not specify what is the current state of the documentation, Uricani did not answer and the Petrosani local administration seems to be the most preoccupied with this purpose, as they are in the final stage of approval.

\section{A vision for Transit Oriented Development in the Jiu Valley}

It is clear that local authorities in the Jiu Valley do not regard strategic management as a necessary instrument for the sustainable development of the Jiu Valley. Even if some local authorities made some steps in the elaboration of LDS, only one of them, Petrosani, decided for an integrated vision for the entire urban area. This municipality collaborated closely to us to create the vision of an open city, one that is now left behind any intention for implementation. In this situation, benefitting from this experience, we propose an integrated system that respects all of the three conditions for a development based on sustainable mobility in the Valley. 


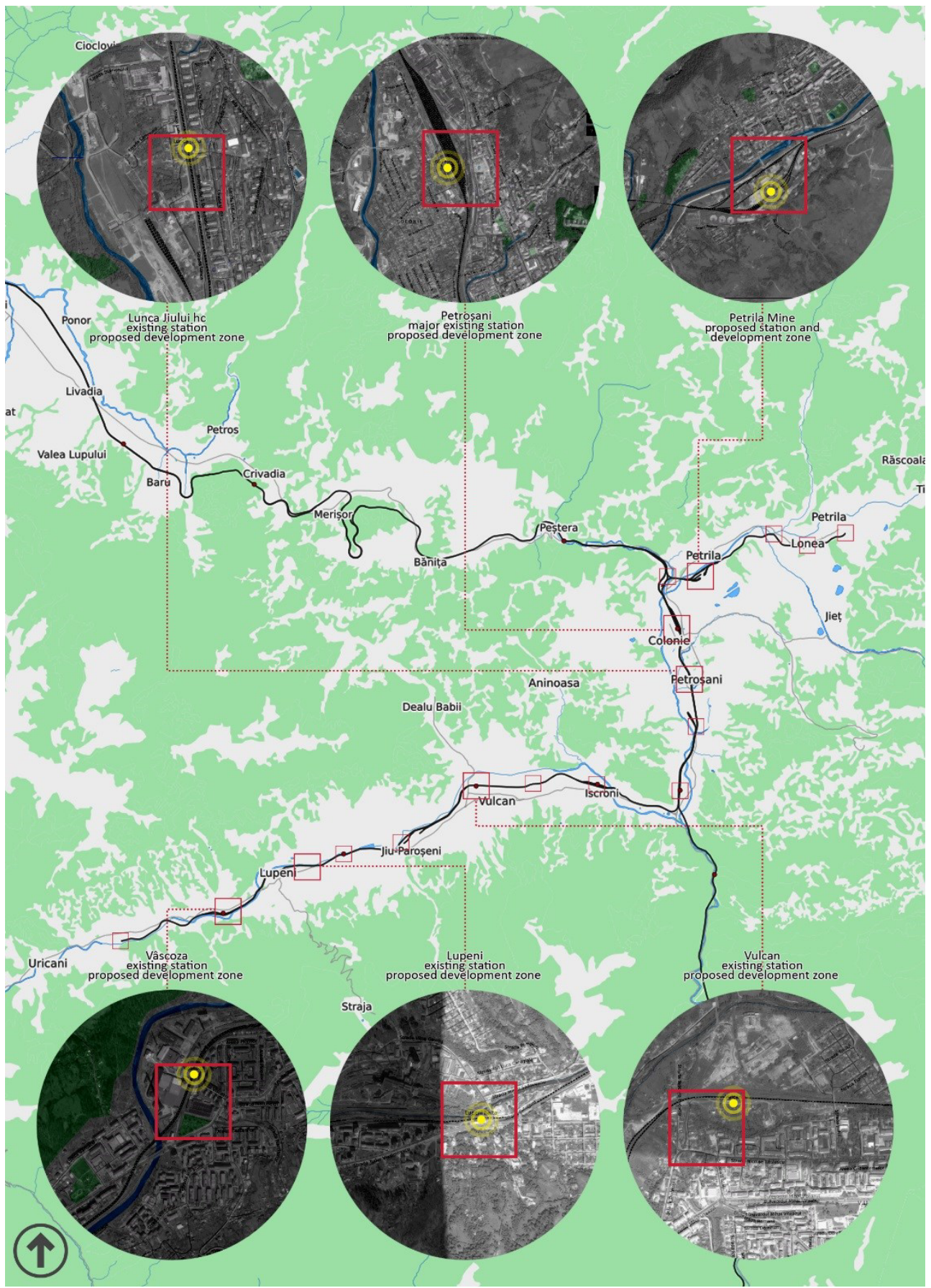

Fig. 1. Main development areas, related to the existent and proposed tram-train stations in the Jiu Valley. Two of the major ones are in Lupeni and two in Petrosani.

The development concept that we propose consists of creating an integrated administrative unit along the Jiu Valley, developed around the new and old city centres that emerge in the regeneration of the urban areas around the railway station and the creation of 
new ones. These main clusters will concentrate the efforts for economic development, being sustained by a main transit system that uses the existing, underused railroad infrastructure. The whole Valley becomes a linear city, limited by an outstanding natural system, traditional rural settlements and modern ski resorts. This is a vision that can streamline the public investment in revitalization of the former mining region and can drive it to survive and adapt to the $4^{\text {th }}$ Industrial Revolution. In this scenario, we see the cities aligned along the unique railroad, taking passengers from Uricani to Petrila in maximum 30 minutes. This needs an administrative body born out of the local administration, in partnership with the railroad company and high capacity local investors.

Petrosani is the focal point, and the most delicate situation. Here, the main station is already the main transportation hub of the Jiu Valley. It benefits from the proximity of the single most important public space in the Valley, Victory square, and of large demolished areas behind it. The main station, itself, has the qualities to be declared a historic monument.

The main objectives for this station are to:

- protect the potential heritage building, restore and revitalize it;

- develop a new business cluster behind the train station, in what is today one of the most degraded neighbourhoods in Petrosani and concentrate here at least a quarter of the city's office spaces and small scale manufactures;

- bring the main bus station close to the train station;

- provide better facilities for passengers, pedestrians and bicyclists;

- restore the urban piazza behind the train station, between the station building and the new office building.

Each of the other train stations need to become a local development hub, layering functions and events, delivering a greater density in the new urban cores. These hubs become new productivity cores, based on the proximity of the transit system and the existence of refurbished former industrial and administrative buildings.

\section{Conclusion and discussion}

In order to implement such a vision, there is the need to put together all the six local administrations and create a unique administrative unit that can manage the entire Jiu Valley. The urban development must be concentrated along the main railroad, making it efficient enough.

The greatest investments must come in the reshaping of the degraded urban contexts around the main train stations and engage local stakeholders in a creativity cluster that can drive the interests of the entire Valley, with a strategic leadership and a vision that stretches over at least 30 years from now on.

\section{References}

1. RP - Romanian Parliament, Law 350/2001 regarding urban planning and the territorial development and its further amendments (2016)

2. RP - Romanian Parliament, Law 50/1991 regarding the approval of constructions and its further amendments (2016)

3. RG - Romanian Government, Emergency Ordinance 100 for the amendment and the completition of Law 350/2001 regarding urban planning and the territorial development and Law 50/1991 regarding the approval of constructions (2016)

4. OECD, OECD Regional Outlook, 2014 - Regions and Cities: Where Policies and People Meet. (2014) http://dx.doi.org/10.1787/9789264201415-en, retrieved 15.04.2017 
5. A. D. Little, Future of urban mobility (2011), http://www.adlittle.com/downloads/tx adlreports/ADL Future of urban mobility.pdf, retrieved 21.04.2017

6. European Comission, High Speed Europe (2010), http://ec.europa.eu/transport/sites/transport/files/themes/infrastructure/studies/doc/2010 high_sp eed rail en.pdf, retrieved 11.04.2017

7. S., Irimie, M.I., Danciu, Proceedings of the $10^{\text {th }}$ International Management Conference, "Challenges of Modern Management", 2016, Bucharest, Romania, http://conferinta.management.ase.ro/archives/2016/PDF/4 5.pdf, retrieved 05.04.2017 